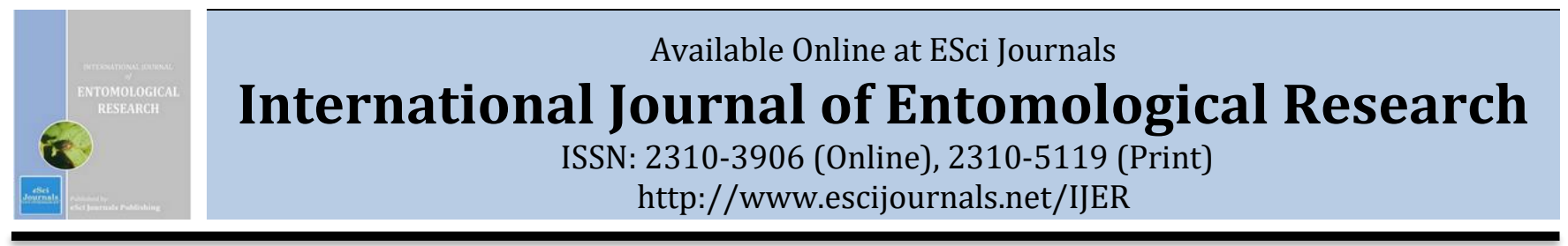

\title{
BIOEFFICACY OF DIFFERENT INSECTICIDES ON COWPEA APHID (APHIS CRACCIVORA KOCH)
}

\author{
Roshan Dhakal*, Reeta Ghimire, Madan Sapkota, Samita Thapa, Atal K. Bhatta, Rajendra Regmi \\ Agriculture and Forestry University, Rampur, Chitwan, Nepal.
}

*Corresponding Author Email: wrotsan@gmail.com

A B S T R A C T

Aphid (Aphis craccivora Koch) is one of the serious pests of cowpea. Bioefficacy of four insecticides with different concentrations namely Jholmol $(125 \mathrm{ml} / \mathrm{L})$, Neemix $(2 \mathrm{ml} / \mathrm{L})$, Cannabis extract ( $100 \mathrm{~g} / \mathrm{L})$, Chlorpyrifos $50 \%$ EC and Cypermethrin 5\% EC (2 ml/L) along with control were evaluated against aphid at Research Station of Agriculture and Forestry University, Rampur, Chitwan, Nepal in 2018. Five treatments; four different insecticides and control were laid out in a randomized complete block design with four replications. The results indicated that all the insecticides were significant for aphid reduction. The effects were higher in Neemix followed by Jholmol and cannabis extract. The yield of cowpea was significantly highest $(11.10 \mathrm{t} / \mathrm{ha})$ with Neemix application, while lowest in control $(7.58 \mathrm{t} / \mathrm{ha})$. The highest net profit (NRs.61670) was obtained in Neemix followed by treatments of Jholmol (NRs.46175) and Cannabis extract (NRs.35815). The lowest incremental Cost/Benefit ratio was obtained in Neemix (1.341) and followed by treatments of, jholmol (1/1.12) and Cannabis extract (1/0.85), respectively. Thus, application of Neemix @ $2 \mathrm{ml} / \mathrm{L}$ could be used in cowpea to control aphid with high yield.

Keywords: Aphid, Aphis craccivora Koch, insecticides, bioefficacy, cowpea.

\section{INTRODUCTION}

Cowpea (Vigna unguiculata Linn.) is the most important legume crop, also known as Lobia, it belongs to family Leguminaceae. It is used as a green legume, fodder, vegetable as well as green manure crop. It is an important source of energy, minerals, vitamins and roughages.

There are about 21 insect pests of different groups which are recorded to damage cowpea crop from germination to maturity (Choudhary et al., 2017). The important insect species attacking cowpea crop are: aphid, Aphis craccivora Koch; jassid, Empoasca fabae (Harris); thrips, Megaleurothrips distalis Karny; armyworm, Mythimna separata (Walker); semilooper, Thysanoplusia orichalcea (Fab.); Leafminer, Phytomyza horticola Meigen and pod borer, Helicoverpa armigera (Hubner) resulting in heavy yield losses (Satpathy et al., 2009). Among these, cowpea aphid, Aphis craccivora Koch is the most serious pest of this crop, causes 20-40 percent yield loss (Choudhary et al., 2017). The sapsucking insects like aphids (A. craccivora Koch) cause considerable damage to the crop and is reported as one of the important, major and economic pests of cowpea (El-Ghareeb et al., 2002). The cowpea aphid, A. craccivora belongs to the family Aphididae of order Hemiptera, suborder Homoptera (Choudhary et al., 2017). The aphid causes both qualitative and quantitative losses in the seed yield and crop production by different ways include: Nutrient drain which cause direct reduction of plant productivity, transmission of viruses, phytotoxicity as a result of saliva toxins and excretion of honeydew leading to the development of black sooty mold and leaf shedding (Kotadia and Bhalani, 1992), which also attract saprophytic fungi covering the leaf surface and accelerating the ageing of leaves (Schepers, 1988).

Integrated pest management (IPM), also known as integrated pest control (IPC) is a broad-based approach that integrates practices for economic control of pests. IPM aims to suppress pest populations below the economic injury level (EIL) IPM emphasizes the growth of a healthy crop with the least possible 
disruption to agro-ecosystems and encourages natural pest control mechanisms. Different methods like the physical, cultural, biological, mechanical, chemical method of pest control are justifiably used to suppress them below EIL. Many research and farmers have emphasized on the use of the insecticides solely based on the chemicals, which are not performing well as expected in the later year in both aspects of production and consumer health. Keeping this aspect, we have done research in regard to comparing different IPM based insecticides (including chemical insecticides) on the aspects of production, aphid count and economic efficiency. Use of plant extracts like Neem (Azadirachta indica) extract, Cannabis sativum extract and use of biological pesticide (Jholmol) are used as biological method whereas the use of chemicals like Chlorpyrifos and Cypermethrin is under the chemical method of IPM.

\section{MATERIALS AND METHODS}

Experimental Site: This experiment was carried out using the cowpea (Variety: Karma Stickless) at Horticultural Research Field of Agriculture and Forestry University, Rampur, Chitwan, Nepal. The geographical location of the experimental field was $27^{\circ} 37^{\prime} \mathrm{N}$ latitude, 84' 25' E longitude at an altitude of 256 meters above sea level and has a subtropical climate (Thapa and Dangol, 1988). The maximum and minimum temperatures of $34.5^{\circ} \mathrm{C}$ and $18.5^{\circ} \mathrm{C}$ respectively, relative humidity of $80-85 \%$ and rainfall of $70-80 \mathrm{~mm}$ were detected during the crop growing period.
Experimental design and field layout: The experiment was laid out in a randomized complete block design (RCBD) with four replications. Three treatments were of biological origin and the fourth one was the chemical origin (Table 1). There were altogether 20 plots, where 5 plots are in each replication. The individual plot size was $3 \mathrm{~m} \times 3 \mathrm{~m}$ keeping row to row and plant to plant distance of $60 \mathrm{~cm}$ and $60 \mathrm{~cm}$, respectively. The seeds of stickless cowpea variety (Karma stickless) was sown on $2^{\text {nd }}$ March 2018 and the recommended package of practices was followed to raise the crop.

Insecticides and their application: Neemix and Chlorpyrifos $50 \%$ EC and Cypermethrin 5\% EC were received from Dawadi Agrovet, Chitwan, Nepal. The cannabis was locally collected. Jholmol was locally prepared. Neem extract was commercially obtained as the trade name "Neemix".

For the preparation of the cannabis extract, the leaves of the mature cannabis plants were dried, and they were ground on the floor. A dose of about $100 \mathrm{~g} / \mathrm{L}$ was made. Similarly, for the preparation of Jholmol, it was prepared by mixing animal urine, animal dungs (Cow dung) and water at 1:1:1 ratio and fermented for 2-3 weeks. Similarly, for the application of the slurry, it was mixed with the water at the ratio of $1: 8$, so that the dose of 125 $\mathrm{ml} / \mathrm{L}$ was made. Also, Neem extracts as Neemix was commercially obtained which was sprayed at the dose of $2 \mathrm{ml} / \mathrm{L}$. The insecticide Chlorpyrifos 50\% EC and Cypermethrin 5\% EC was sprayed at the dose of $2 \mathrm{ml} / \mathrm{L}$.

Table 1. Name of different insecticides used in the experiment along with their origin and dose.

\begin{tabular}{clcc}
\hline Sr. No. & \multicolumn{1}{c}{ Treatments } & Origin & Dose \\
\hline 1 & Jholmol & Bio-pesticide & $125 \mathrm{ml} / \mathrm{L}$ \\
2 & Neem extract (Trade Name: Neemix) & Bio-pesticide & $2 \mathrm{ml} / \mathrm{L}$ \\
3 & Cannabis extract & Bio-pesticide & $100 \mathrm{~g} / \mathrm{L}$ \\
4 & Chloropyrifus 50 \% EC and Cypermethrin 5\% EC & Chemical & $2 \mathrm{ml} / \mathrm{L}$ \\
5 & Control (normal water) & - & - \\
\hline
\end{tabular}

All the insecticides were applied as a foliar spray. The spraying was done by using a 16 Liter knapsack sprayer. The first insecticides spray was done on the $23^{\text {rd }}$ of March. About 3 sprays of chemical insecticide were done at the 15 days interval. Similarly, the other insecticides of biological origin were sprayed 3 times about weekly interval.

Data collection: The five randomly selected plants inside each plot were tagged, and observation on the aphid population was taken from the tagged plants on three leaves, each from the top, middle and bottom canopy of plants in each plot. Aphid population was counted one day before and 3, 5 and 7 days after application of insecticides. The observations on aphid population were recorded by visual counting method. The crop was harvested when pods reached full maturity. Pod yield is calculated from the tagged plant inside each plot. Pod yield per plot was converted into quintal per hectare and yield data was statistically analyzed. 
The data thus obtained were taken into consideration to calculate the percentage reduction in the population which was determined by applying a correction factor given by Henderson and Tilton referring it to Abbott modification (Püntener, 1981);

Percentage reduction $=100 \times[1-\{(\mathrm{Ta} \times \mathrm{Cb}) /(\mathrm{Tb} \times \mathrm{Ca})\}]$ Where;

$\mathrm{T}_{\mathrm{a}}=$ Number of insects after treatment.

$\mathrm{T}_{\mathrm{b}}=$ Number of insects before treatment.

$\mathrm{C}_{\mathrm{a}}=$ Number of insects in untreated control after treatment.

$\mathrm{C}_{\mathrm{b}}=$ Number of insects in untreated control before treatment.

\section{Economics analysis}

Cost of treatments: Cost of different insecticide: Neem extract (Neemix): NRs.160 for $100 \mathrm{ml}$, Cannabis extract: NRs. 35/kg, Jholmol: NRs. 50/L and Chemical (Chlorpyriphos 50\% EC and Cypermethrin 5\% EC) =NRs.200 for $100 \mathrm{ml}$., Labor charge: NRs 1000/ha, the Market price of cowpea: NRs. $25 / \mathrm{kg}$ pod.

Net return (NRs. /ha): This was calculated separately by subtracting the cost of treatment from additional income of respective treatment.

Incremental Cost-Benefit ratio: This was calculated separately for each treatment as per the following formulae suggested by (Chejara, 2013).

Incremental Cost-Benefit ratio $($ ICBR $)=$ Net return/Cost of treatment.

Statistical analysis: The analysis was carried out by transforming the percentage reduction data into angular transformation values (Gomez and Gomez, 1984). Microsoft Excel was used and statistical software, R stat was done for the statistical analysis.

\section{RESULTS AND DISCUSSION}

First insecticidal application: After the insecticide's application, all the treatments were found significantly different than the untreated control (Table 2). At the $3^{\text {rd }}$ day, the effect of Neem extract of dose $2 \mathrm{ml} / \mathrm{L}$ was found significantly higher for aphid population reduction $(90.17 \%)$ than the other treatments over control. The chemical treatment of Chlorophyriphos50\% EC and Cypermethrin5\% EC ( $2 \mathrm{ml} / \mathrm{L})$ was found similar to the Neem extract and with Jholmol. The cannabis extract was found significantly lower than the other insecticides treatments having percent reduction over control value of $66.16 \%$.

Table 2. Effects of insecticides on percent reduction of cowpea aphid population after $1^{\text {st }}$ spray

\begin{tabular}{llcccc}
\hline \multirow{2}{*}{ Sr. No. } & \multirow{2}{*}{ Insecticides } & \multicolumn{4}{c}{ Percent reduction of aphid over control after 1st spray } \\
\cline { 3 - 6 } & & $3^{\text {rd }}$ day after spray & $5^{\text {th }}$ day after spray & $7^{\text {th }}$ day after spray & Mean \\
\hline 1 & Jholmol & $78.36^{\mathrm{b}}$ & $73.86^{\mathrm{b}}$ & $62.08^{\mathrm{bc}}$ & $71.67^{\mathrm{b}}$ \\
& & $(62.28)$ & $(59.25)$ & $(51.99)$ & $(57.84)$ \\
\hline 2 & Neem extract (Neemix) & $90.17^{\mathrm{a}}$ & $96.26^{\mathrm{a}}$ & $88.9^{\mathrm{a}}$ & $91.75^{\mathrm{a}}$ \\
& & $(71.73)$ & $(78.85)$ & $(70.55)$ & $(73.71)$ \\
\hline \multirow{2}{*}{3} & $66.16^{\mathrm{c}}$ & $55.09^{\mathrm{b}}$ & $39.04^{\mathrm{c}}$ & $53.51^{\mathrm{c}}$ \\
& Cannabis extract & $(54.43)$ & $(47.92)$ & $(38.67)$ & $(47.01)$ \\
\hline 4. & Chloropyriphos 50\% EC & $75.36^{\mathrm{b}}$ & $79.16^{\mathrm{ab}}$ & $62.92^{\mathrm{b}}$ & $74.91^{\mathrm{b}}$ \\
& and Cypermethrin 5\% EC & $(60.24)$ & $(62.84)$ & $(56.74)$ & $(59.94)$ \\
\hline 5 & Control (water) & - & - & - & - \\
\hline & CV (\%) & 10.5 & 13.6 & 12.9 & 8.79 \\
\hline & LSD & 10.4 & 11.6 & 12.8 & 8.08 \\
\hline
\end{tabular}

Means with the same letter do not differ significantly at $p=0.05$ by DMRT. CV = Coefficient of variation. LSD $=$ least significant difference. The figures in the parentheses are the angular transformed values.

At the $5^{\text {th }}$ day after the $1^{\text {st }}$ insecticides application, the effect of Neem extract was found significant $(96.26 \%$ reduction for aphid) than the other treatments over control. The effect of cannabis extract on aphid reduction was found lower than the other insecticidal treatments.

Similarly, on the $7^{\text {th }}$ day of the $1^{\text {st }}$ insecticides treatment, again the effect of Neem extract was found significantly higher (88.9\% reduction in aphid) than the other treatments over control. After that, chemical treatment was significantly similar to Jholmol but superior to cannabis extract. Jholmol and cannabis extract was found significantly similar. The effect of cannabis extract was significantly lower than the other insecticides treatments with a $39.04 \%$ reduction over control.

After the $1^{\text {st }}$ insecticides treatment, the overall effect was found to be significantly higher at Neem extract which was followed by chemical treatment. The chemical 
treatment was found significantly similar to the Jholmol which was followed by cannabis extract.

Second insecticidal application: Similarly, after the $2^{\text {nd }}$ insecticidal treatment, the effects of all the insecticides treatments were found significantly higher than the untreated control (Table 3). At the $3^{\text {rd }}$ day after the $2^{\text {nd }}$ insecticidal treatment, effect of Chlorpyriphos $50 \%$ EC and Cypermethrin 5\% EC was found significantly higher (96.70\% aphid reduction) than the other treatments over control. The chemical treatment was found significantly similar to the Neem extract and also to Jholmol. Similarly, Jholmol was found significantly similar to the cannabis extract and cannabis extract was found significantly lower than the insecticides treatment with the $66.18 \%$ reduction over control.

At the $5^{\text {th }}$ day after the $2^{\text {nd }}$ insecticides treatments, instead of Neem extract, the chemical treatment was found significantly superior to the other treatments with the $77.31 \%$ reduction over control. It was found similar to the Neem extract. Neem extract was found significantly similar to the Jholmol, whereas the effect of cannabis extract was found significantly lower than the other insecticides treatment.

At the $7^{\text {th }}$ day after the $2^{\text {nd }}$ insecticides treatments, again the chemical treatment was found significantly higher than the other treatments. It was found similar to the Neem extract. Neem extract was found significantly similar with the Jholmol and Cannabis extract. Jholmol was found significantly similar with the cannabis extract which were found significantly lower than the other insecticides treatment.

After the $2^{\text {nd }}$ insecticides treatments, the overall effect was found to be significantly higher in Neem extract which was found significantly similar to the Chlorpyriphos 50\% EC and Cypermethrin 5\% EC and followed by Jholmol. The effect of cannabis extract was significantly lower among all the insecticidal treatment which is significantly similar to the Jholmol.

Table 3. Effects of insecticides on percent reduction of cowpea aphid population after $2^{\text {nd }}$ spray.

\begin{tabular}{llcccc}
\hline \multirow{2}{*}{ Sr. No. } & \multirow{2}{*}{ Insecticides } & \multicolumn{3}{c}{ Percent reduction of aphid over control after 2 $2^{\text {nd }}$ spray } & Mean \\
\cline { 3 - 6 } & & $3^{\text {rd }}$ day after spray & $5^{\text {th }}$ day after spray & $7^{\text {th }}$ day after spray & \\
\hline \multirow{2}{*}{ Jholmol } & $77.31^{\mathrm{bc}}$ & $47.87^{\mathrm{b}}$ & $64.89^{\mathrm{b}}$ & $63.77^{\mathrm{b}}$ \\
& & $(61.55)$ & $(43.78)$ & $(53.66)$ & $(52.99)$ \\
\hline \multirow{2}{*}{ Neem extract (Neemix) } & $90.44^{\mathrm{ab}}$ & $77.31^{\mathrm{a}}$ & $93.93^{\mathrm{a}}$ & $88.03^{\mathrm{a}}$ \\
& & $(71.99)$ & $(61.55)$ & $(75.74)$ & $(69.76)$ \\
\hline 3 & $66.18^{\mathrm{c}}$ & $28.81^{\mathrm{c}}$ & $54.32^{\mathrm{b}}$ & $49.63^{\mathrm{b}}$ \\
& Cannabis extract & $(54.44)$ & $(32.463)$ & $(47.48)$ & $(44.79)$ \\
\hline 4. & Chloropyriphos 50\%EC & $96.70^{\mathrm{a}}$ & $65.87^{\mathrm{ab}}$ & $88.2^{\mathrm{ab}}$ & $85.87^{\mathrm{a}}$ \\
& and Cypermethrin 5\% EC & $(79.53)$ & $(54.28)$ & $(69.95)$ & $(67.922)$ \\
\hline 5 & Control (water) & - & - & - & - \\
\hline & CV (\%) & 15.7 & 14.6 & 13.8 & 10.2 \\
\hline & LSD & 16.8 & 11.2 & 13.6 & 9.6 \\
\hline
\end{tabular}

Means with the same letter do not differ significantly at $p=0.05$ by DMRT. CV = Coefficient of variation. LSD $=$ least significant difference. The figures in the parentheses are the angular transformed values.

Third insecticidal application: Similarly, after the $3^{\text {rd }}$ insecticides treatment, the effect of all the insecticides treatments were found significantly higher than the untreated control (Table 4). At the $3^{\text {rd }}$ day after the $3^{\text {rd }}$ insecticides treatment, effect of neem extract was found significantly higher than the other treatments with the $93.60 \%$ reduction over control. Chemical treatment and Jholmol were found significantly similar to each other and Neem extract. They were also found significantly similar to the Cannabis extract which was found significantly lower than the other insecticides treatments.
At the $5^{\text {th }}$ day after the 3rd insecticide application, instead of Neem extract, the chemical treatment was found significantly higher than the other treatments with the $66.41 \%$ reduction in aphid population over control. It was found similar to the Neem extract. Neem extract was found significantly similar with the Jholmol and Jholmol was found significantly similar to the Cannabis extract which was found significantly lower than the other insecticides treatments.

At the $7^{\text {th }}$ day, Neem extract was found significantly superior to the other treatments. The chemical treatment was found significantly similar to all the 
insecticides treatments. Similarly, Jholmol was found significantly similar to the Cannabis extract and Cannabis extract was found significantly lower than the insecticides treatment with the $66.41 \%$ reduction over control.
After the $3^{\text {rd }}$ insecticides treatment, again, the overall effect was found to be significantly higher in Neem extract which is similar to Chlorpyriphos $50 \%$ EC and Cypermethrin 5\% EC and followed by Jholmol which was significantly similar to the Cannabis extract.

Table 4. Effects of insecticides against the cowpea aphid population after $3^{\text {rd }}$ spray.

\begin{tabular}{|l|l|l|l|l|l|}
\hline \multirow{2}{*}{ Sr. No. } & \multirow{2}{*}{ Insecticides } & \multicolumn{3}{|c|}{ Percent reduction of aphid over control after $3^{\text {rd }}$ spray } \\
\cline { 3 - 6 } & & $3^{\text {rd }}$ day after spray & $5^{\text {th }}$ day after spray & $7^{\text {th }}$ day after spray & \multicolumn{1}{c|}{ Mean } \\
\hline 1 & \multirow{2}{*}{ Jholmol } & $79.87^{\mathrm{ab}}$ & $30.21^{\mathrm{bc}}$ & $65.83^{\mathrm{bc}}$ & $59.21^{\mathrm{b}}$ \\
& & $(63.34)$ & $(33.34)$ & $(54.23)$ & $(50.31)$ \\
\hline 2 & Neem extract (Neemix) & $93.60^{\mathrm{a}}$ & $49.41^{\mathrm{ab}}$ & $88.95^{\mathrm{a}}$ & $80.13^{\mathrm{a}}$ \\
& & $(75.35)$ & $(44.66)$ & $(70.58)$ & $(63.53)$ \\
\hline 3 & Cannabis extract (Ganja) & $66.41^{\mathrm{b}}$ & $17.30^{\mathrm{c}}$ & $51.66^{\mathrm{c}}$ & $44.25^{\mathrm{b}}$ \\
& & $(54.58)$ & $(24.58)$ & $(45.95)$ & $(41.70)$ \\
\hline 4. & Chloropyriphos 50\% EC & $85.34^{\mathrm{ab}}$ & $66.41^{\mathrm{a}}$ & $81.78^{\mathrm{ab}}$ & $78.35^{\mathrm{a}}$ \\
& and Cypermethrin 5\% EC & $(67.49)$ & $(54.58)$ & $(64.73)$ & $(62.27)$ \\
\hline 5 & Control (water) & - & - & - & - \\
\hline 6. & CV (\%) & 13 & 18.5 & 11.9 & 11.5 \\
\hline 7 & LSD & 13.6 & 11.7 & 11.2 & 10 \\
\hline
\end{tabular}

Means with the same letter do not differ significantly at $p=0.05$ by DMRT. CV = Coefficient of variation. LSD= least significant difference. The figures in the parentheses are the angular transformed values.

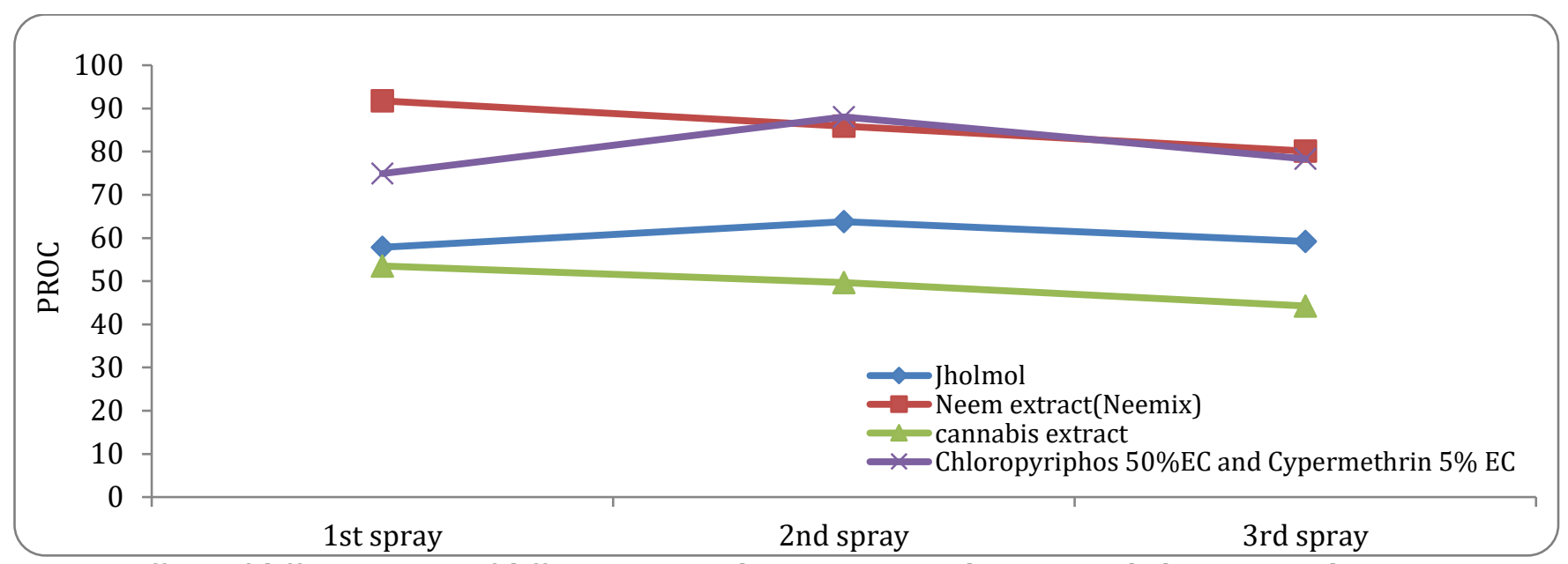

Figure1. Effects of different sprays of different insecticides on percent reduction in aphid over control.

Neem extract was more effective than all treatments (Figure 1). Azadirachtin is a chemical complex found in seeds of neem, Azadirachta indica, A. Juss, it is the main component responsible for the toxic, repellent, anti-feed ant, growth-inhibiting, oviposition-inhibiting and sterilizing effects in insects (Kumar and Navaratnam, 2013; Mordue and Nisbet, 2000). The extract of this plant reduces the population of several aphid species, causing high mortality and decreasing fecundity, as well as inhibiting population growth (Partridge and Borden, 1997; Tang et al., 2002; Ulrichs et al., 2001). The use of a chemical method was also very effective. It is a special combination insecticide contains chlorpyrifos (organophosphorus compound) and cypermethrin (pyrethroid compound) which means a special efficiency to control a wide range of soil and foliar insects which acts as strong contact, stomach and respiratory action. Similarly, the application of Jholmol contributed to increased farm production with a lesser attack of insects and diseases (LWF Nepal, 2017). The effectiveness of the cannabis extract is minimum than the other insecticides treatments, but it is highly significant than the control. 
Effects of insecticides on the yield of cowpea: The pod yield of cowpea under all the insecticides treatments were significantly higher over control. Neem extract produced the highest pod yield of $11.10 \mathrm{t} / \mathrm{ha}$ which was significantly higher than the other all treatments. Similarly, the chemical treatments were significantly similar to the Neem extract and Cannabis extract, which produced a yield of $10.33 \mathrm{t} / \mathrm{ha}$.
Among the insecticide's treatments, Cannabis extract produced the lowest yield of $9.18 \mathrm{t} / \mathrm{ha}$ but it was also significantly higher than the control and significantly similar to the Jholmol and chemical treatment.

The similar type of trend is obtained from the effectiveness of the insecticide's treatments on the basis of aphid reduction over control.

Table 5. Effects of insecticides on the yield of Cowpea.

\begin{tabular}{|c|c|c|}
\hline Sr. No. & Treatments & Yield (t/ha) \\
\hline 1 & Jholmol & $10.56^{\mathrm{ab}}$ \\
\hline 2 & Neem extract (Neemix) & $11.10^{\mathrm{a}}$ \\
\hline 3 & Cannabis extract & $9.18^{\mathrm{b}}$ \\
\hline 4 & Chloropyrifus 50\% EC and Cypermethrin 5\% EC & $10.33^{\mathrm{ab}}$ \\
\hline \multirow[t]{3}{*}{5} & Control (water) & $7.58^{\mathrm{c}}$ \\
\hline & CV (\%) & 10 \\
\hline & $\mathrm{LSD}_{0.05}$ & 1.51 \\
\hline
\end{tabular}

Means with the same letter do not differ significantly at $p=0.05$ by DMRT. CV $=$ Coefficient of variation, LSD $=$ least significant difference.

Similar results were reported by Baidoo et al. (2012), that neem products were effective in controlling $A$. craccivora on cowpea. They reported that the aqueous product of the neem extract was effective against the Aphis craccivora, the yield was better than that on the control plots and yield from the neem-treated plots, also compared favourably with that of the insecticide-treated plots. Similarly, Prasannath and Mahendran (2013) revealed that neem seed extract $5 \%$ showed a significant reduction $(\mathrm{P}<0.05)$ in aphid population and his study elucidates that use of neem seed extract $5 \%$ could be suggested to manage the cowpea pests as it has been found to have very promising bioefficacy against this pest.

Economics of insecticides application: The highest net profit was obtained in Neem extract which was NRs.61670 among the insecticides treatment which is followed by chemical treatment, Jholmol and cannabis extract with the net profit of NRs.46175, NRs. 35815 and NRs.16696 respectively. Similarly, the Incremental CostBenefit Ratio (ICBR) was observed from 1/3.14 to 1/0.85. Among the insecticide's treatment, lowest Cost/Benefit ratio $(1 / 3.14)$ was obtained in Neem extract and followed by chemical treatment (1/2.85), jholmol (1/1.12) and cannabis extract (1/0.85).

Table 6. Economics of different insecticides applications against aphid on cowpea.

\begin{tabular}{clccccc}
\hline Sr. No. & \multicolumn{1}{c}{ Treatments } & $\begin{array}{c}\text { Cost of } \\
\text { treatments } \\
\text { (NRS. / ha) }\end{array}$ & $\begin{array}{c}\text { Yield } \\
\text { (t/ha) }\end{array}$ & $\begin{array}{c}\text { Gross } \\
\text { return } \\
\text { (NRs/ha) }\end{array}$ & $\begin{array}{c}\text { Net profit } \\
\text { over } \\
\text { control }\end{array}$ & $\begin{array}{c}\text { Incremental cost } \\
\text { benefit-cost ratio } \\
\text { (ICBR) }\end{array}$ \\
\hline 1 & Jholmol & 31760 & 10.56 & 67575 & 35815 & $1: 1.12$ \\
2 & Neem extract (Neemix) & 18080 & 11.10 & 79750 & 61670 & $1: 3.41$ \\
3 & Cannabis extract (Ganja) & 19554 & 9.18 & 36250 & 16696 & $1: 0.85$ \\
4 & Chloropyrifus 50 EC and Cypermethrin EC & 16200 & 10.33 & 62375 & 46175 & $1: 2.85$ \\
5 & Control (water) & - & 10.56 & - & - & - \\
\hline
\end{tabular}

The effective value of the IBCR for different IPM methods suggests that they were economic, which is the core theme of IPM. Similar finding was obtained by Jackai (1993) who reviewed the current status of the use of neem (Azadirachta indica A. Juss) on cowpea, which shows due to the high cost and unavailability of the conventional insecticide, the use of neem extract has been intensified (Singh et al., 1997) as it is relatively cheap, available and effective.

\section{CONCLUSION}

Neemix (neem extract) was more effective insecticide against cowpea aphids. Neemix treated plots produced higher yield and economic returns. Moreover, other plant extracts namely cannabis extract, Jholmol were also found relatively effective insecticides, so their commercialization is necessary for pest control.

\section{ACKNOWLEDGEMENTS}

The authors acknowledge Agriculture and Forestry 
University for providing funds and research filed for carrying out these experiments. They were also grateful for the CARITAS, Nepal for providing technical support.

\section{REFERENCES}

Baidoo, P. K., D. Baidoo-Ansah and I. Agbonu. 2012. Effects of neem (Azadirachta indica A. Juss) products on Aphis craccivora and its predator Harmonia axyridis on cowpea. American Journal of Experimental Agriculture, 2: 198-206.

Chejara, B. K. 2013. Studies on Gram Pod Borer, Helicoverpa armigera (Hub.) on Chickpea and its control with insecticides and biopesticides (Unpublished) M.Sc. thesis, Jawaharlal Nehru Krishi Vishwavidyalaya, Jabalpur, M.P., India.

Choudhary, A. L., A. Hussain, M. D. Choudhary, R. Samota and S. Jat. 2017. Bioefficacy of newer insecticides against aphid, Aphis craccivora Koch on cowpea. Journal of Pharmacognosy and Phytochemistry, 6: 1788-1792.

El-Ghareeb, A. M., M. A. K. Nasser, A. M. K. El-Sayed and G. A. Mohamed. 2002. Possible mechanisms of insecticide resistance in the cowpea aphid Aphis craccivora Koch 11 The role of general estrase and oxidase enzymes in insecticide resistance of cowpea aphid. Nepal's First Conference on Agriculture: 635-649.

Gomez, A. A. and K. A. Gomez. 1984. Statistical procedures for agricultural research. Statistical Procedures for Agricultural Research, 6: 680.

Jackai, L. E. N. 1993. The use of Neem in controlling cowpea pests. UTA Research, 7: 5-11.

Kotadia, V. S. and P. A. Bhalani. 1992. Residual toxicity of some insecticides against Aphis craccivora Koch on cowpea crop. Gujarat Agricultural University Research Journal, 17: 161-164.

Kumar, V. S. and V. Navaratnam. 2013. Neem (Azadirachta indica): prehistory to contemporary medicinal uses to humankind. Asian Pacific journal of tropical biomedicine, 3: 505-514.

LWF Nepal. 2017. Identification and Scientific Documentation of the Indigenous Eco-friendly and Climate-resilient Agricultural Practices in Nepal, p. 11-15.
Mordue, A. J. and A. J. Nisbet. 2000. Azadirachtin from the neem tree Azadirachta indica: its action against insects. Anais da Sociedade Entomológica do Brasil, 29: 615-632.

Partridge, M. J. and J. H. Borden. 1997. Evaluation of neem seed extract for control of the spruce aphid, Elatobium abietinum (Walker) (Homoptera: Aphidae). Canadian Entomologist, 129: 899-906.

Prasannath, K. and S. Mahendran. 2013. Efficacy of botanicals on the control of cowpea pests. International Conference of Eastern University. Eastern University, Sri Lanka.

Püntener, W. 1981. Manual for field trials in plant protection second edition. Agricultural Division, Ciba-Geigy Limited, Delhi, India.

Satpathy, S., T. M. Shivalingaswami, A. Kumar, A. B. Raj and M. Rai. 2009. Efficacy of biopesticides and new insecticides for managements of cowpea pod borer, Maruca vitrata. International conference on grain legumes: Quality improvement value addition and trade.

Schepers, A. 1988. Aphids- their biology, natural enemies and control. World Crop Pests, 2C. Elsevier, Amsterdam, p. 89-121.

Singh, B. B., D. R. MohanRaj and K. E. Dashiell. 1997. Advances in cowpea research. Japan International Research Center for Agricultural Sciences (JIRCAS), Tsukuba, Japan, p. 375.

Tang, Y. Q., Weathersbee, A. A. III and R. T. Mayer. 2002. Effect of neem seed extract on Brown citrus aphid (Homoptera: Aphididae) and its parasitoid Lysiphlebus testaceipes (Hymenoptera: Aphidiidae). Environmental Entomology, 31: 172-176.

Thapa, R. B. and D. R. Dangol. 1988. A preliminary survey of weed flora at IAAS and its vicinity, In: F. P. Neupane, (ed.), IAAS Research Report (19851991). Institute of Agriculture and Animal Science, Rampur, Chitwan, Nepal. p. 59-65.

Ulrichs, C. H., I. Mewis and W. H. Schnitzler. 2001. Efficacy of neem and diatomaceous earth against cowpea aphids and their deleterious effect on predating Coccinelidae. Journal of Applied Entomology, 125: 571-575.

Publisher's note: ESci Journals Publishing remains neutral with regard to jurisdictional claims in published maps and institutional affiliations.

Open Access This article is licensed under a Creative Commons Attribution 4.0 International License. To view a copy of this license, visit http://creativecommons.org/licenses/by/4.0/.

(C) The Author(s) 2019 
Int. J. Entomol. Res. 07 (01) 2019 - 01-07

DOI: $10.33687 /$ entomol.007.01.2629 